\title{
ASUHAN KEPERAWATAN PADA KLIEN DENGAN KISTA ENDOMETRIOSIS MENGGUNAKAN PENDEKATAN TEORI COMFORT DAN LOSS \& GRIEF
}

\author{
Oleh: Marlinda ${ }^{1}$, Yati Afiyati ${ }^{2}$, Tri Budiati ${ }^{3}$ \\ STIKes Muhammadiyah pringsewu Lampung1, Fakultas Ilmu Keperawatan Universitas Indonesia ${ }^{2} 3$ \\ Email: elin1978@yahoo.com
}

\begin{abstract}
ABSTRAK
Kista endometriosis atau chocolate cyst adalah tumor jinak yang sering terjadi pada sistem reproduksi perempuan saat ini. Perempuan dengan masalah ini akan mengalami gangguan pada kualitas hidup seorang perempuan baik secara fisik, psikospiritual, lingkungan maupun sosiokultural. Resiko lainnya adalah timbulnya keganasan pada sistem reproduksi. Tujuan dari laporan ini adalah memberikan gambaran tentang pelaksanaan praktik penelitisi ners spesialis yaitu pengelolaan kasus klien kista endometriosis dengan pendekatan studi kasus yang menerapkan teori comfort dan loss \& grief. Asuhan diberikan untuk mengatasi ketidaknyamanan yang dialami klien baik secara fisik, psikospiritual, lingkungan dan sosiokultural, pada saat penatalaksanaan pembedahan dilakukan pada klien. Pemilihan konsep teori keperawatan comfort yang dielaborasi dengan teori loss \& grief dapat saling melengkapi sehingga asuhan yang diberikan dapat lebih maksimal.
\end{abstract}

Kata kunci: comfort, kista endometriosis, Loss \& Grief, nyeri.

\begin{abstract}
Endometriosis cysts or chocolate cyst is a benign tumor that often occurs in the female reproductive system at this time. Women with this problem would be impaired on a woman's quality of life both physically, psychospiritual, environment, and socio-cultural. Another risk is the incidence of malignancies of the reproductive system. The purpose of this report is to provide an overview of the implementation of the practice peneliticy specialist nurses are managing client cases cysts of endometriosis with a case study approach to apply the theory of comfort and loss and grief. Care given to overcome the discomfort experienced by clients both physically, psychospiritual, environmental and socio-cultural, management during surgery is done on the client. Selection of comfort nursing theory concepts elaborated the theory of loss and grief can be complementary so that the care provided can be maximized.
\end{abstract}

Keywords: comfort, endometriosis cysts, loss \& grief, pain 


\section{PENDAHULUAN}

Kista endometriosis atau kista coklat merupakan suatu lesi yang berada di ovarium (Yamashita \& Toyokuni, 2012). Kista endometriosis sebanyak 5-10\% dapat ditemukan pada perempuan usia reproduksi (Kim, Chae, Kim \& Kang, 2013; Harzif, 2014; Murray \& McKinney, 2007; Iafrate, et.al. 2012). Kejadian endometriosis diperkirakan terjadi pada $7-10 \%$ perempuan pada populasi umum, dan $2-50 \%$ terjadi pada perempuan infertil serta $71-87 \%$ perempuan akan mengalami nyeri kronik (Ozawa, Murakami \& Terada, 2006; Ozkan \& Arici, 2009). Kista endometriosis tidak hanya mengakibatkan nyeri pada saat haid atau di luar siklus haid, namun kondisi ini dapat mengganggu ovulasi, mengganggu kondisi organ reproduksi bagian dalam sehingga interaksi sel telur dan sperma terganggu dan mengganggu implantasi (Harzif, 2014; Ricci \& Kyle, 2009).

Ozkan dan Arici (2009) menegaskan dalam ulasannya bahwa akibat dari kista endometriosis yaitu nyeri dan infertil yang dapat menghancurkan dan berpengaruh terhadap kondisi fisik, mental dan kehidupan sosial seorang perempuan serta kualitas hidupnya secara keseluruhan, dan resikonya menjadi tujuh kali lebih besar jika ibu atau saudara perempuannya mempunyai riwayat penyakit yang sama atau penyakit keganasan yang lainnya (Matalliotakis, 2010; Yamashita, \& Toyokuni, 2012). Sebagian besar perempuan masih meyakini bahwa bila seorang perempuan mengalami kista pada saluran reproduksinya kemandulan akan menghantui kehidupan rumah tangganya kelak (Solomon, 2014). Perawat maternitas sebagai salah satu tenaga kesehatan berperan penting dalam penatalaksanaan masalah kesehatan perempuan khususnya pada kasus klien dengan kista endometriosis.

Tindakan pembedahan menjadi alternatif terakhir dari masalah klien dengan kista endometriosis walaupun tindakan ini dapat menimbulkan efek samping atau komplikasi baik secara fisik, psikologis dan sosial ekonomi. Ketidaknyamanan-ketidaknyamanan secara fisik, psikospiritual, lingkungan dan sosiokultural akan dirasakan oleh klien selama menjalani perawatan perioperatif untuk mengangkat jaringan kista (cystectomy), pengangkatan rahim (hysterectomy), tuba faloppii (salfingectomy) dan ovarium (oophorectomy).

Hal ini bila tidak ditatalaksana dengan baik akan membuat klien mengalami masalah lain yang lebih kompleks seperti cemas sampai dengan takut, nyeri hebat, infeksi, kehilangan yang kronis, ketidakmampuan perempuan memiliki keturunan, permasalahan rumah tangga (hubungan suami istri) dan kekambuhan dari penyakit.

Konsep Teori Comfort dengan melihat pada empat konteks kenyamanan yang dapat terjadi 
pada klien, meliputi kenyamanan secara fisik, psikospiritual, lingkungan dan sosiokultural (Kolcaba, K., Tilton, C. \& Drouin, C., 2006) dapat diterapkan dalam memberikan asuhan pada klien perioperatif dengan penyakit kista endometriosis. Teori Comfort secara komprehensif dan melihat manusia secara utuh digunakan untuk memfasilitasi klien mendapatkan kenyamanan-kenyamanan atas ketidaknyamanan yang dapat terjadi selama proses asuhan keperawatan perioperatif diberikan. Pendekatan Teori Comfort di kembangkan dalam ilmu keperawatan yang diperkenalkan oleh Katharine Kolcaba (Tomey \& Alligood, 2010; Peterson \& Bredow, 2004).

Ketidaknyamanan secara psikospiritual yang dialami oleh klien selama perawatan perioperatif dielaborasikan dengan konsep Loss dan Grief dari Kubler-Ross. Klien dengan kista endometriosis yang harus dilakukan pembedahan untuk pengangkatan kista atau jaringan dan organ dimana kista berada, akan menimbulkan respon psikologis yang berbedabeda. Tahapan respon psikologis terhadap kehilangan terutama organ tubuh yang dianggap sebagai organ vital bagi seorang perempuan perlu diperhatikan seorang perawat maternitas. Karena respon maladaptif secara psikologis dari klien terhadap proses kehilangan akan mempengaruhi kondisi fisik, lingkungan, dan sosiokultural. Setelah diberikan perawatan secara komprehensif diharapkan klien dapat menerima kondisinya saat ini dan melanjutkan kehidupannya di masa datang bersama pasangan dan keluarga dengan lebih baik dari sebelum dilakukan pembedahan.

\section{METODOLOGI}

Penelitian ini adalah penelitian kualitatif dengan menggunakan pendekatan case study. Penelitian ini melibatkan dua partisipan dengan kista endometriosis yang dirawat di ruang rawat Rumah Sakit Ciptomangunkusumo Jakarta. Tujuan penelitian ini adalah untuk menggambarkan klien dengan focus of interest teori keperawatan Comfort Kolcaba dan LossGrief Kubler-Ross dalam memberikan asuhan keperawatan pada klien dengan kista endometriosis

\section{HASIL DAN PEMBAHASAN \\ Hasil}

Teori keperawatan Comfort Kolcaba dan Loss \& Grief Kubler-Ross diterapkan pada dua kasus klien kelolaan kista endometriosis dengan masalah utama nyeri dan distress. Asuhan keperawatan dilakukan menggunakan lima tahap proses keperawatan yaitu pengkajian, diagnosis, intervensi, implementasi dan evaluasi. Berikut ini gambaran pelaksanaan aplikasi teori pada kasus kelolaan. Kasus kelolaan dengan penerapan konsep dan teori tersebut sebagaimana berikut di bawah ini:

\section{Gambaran kasus 1}

Ny. R.U. 44 tahun, P2 A2. Muslim, ibu rumah tangga (IRT), Post operasi Histerektomi, 
Salfingektomi, Oophorektomi sinistra (HT SOS) atas indikasi adenomiosis dan kista endometriosis sinistra, hari pertama. Klien mengeluh nyeri pada ulu hati dan luka operasi, perut kembung, mual, dan banyak keringat. Pemeriksaan fisik TD: 150/90 $\mathrm{mmHg}, \mathrm{N}: 83$ x.menit, S: $36^{\circ} \mathrm{C}, \quad \mathrm{RR}: 24 \mathrm{x} / \mathrm{menit}$, VAS 6 . Abdomen terdapat luka operasi secara vertical, panjang sekitar $15 \mathrm{~cm}$, luka tertutup perban, perut kembung, bising usus positif, dan nyeri tekan positif. Terpasang dower chateter, infus, tranfusi PRC kolf kedua paska operasi. Klien menangis karena merasa sedih rahimnya sudah tidak ada lagi merasa ketakutan. Klien belum dapat mobilisasi bertahap miring kanan miring kiri karena merasakan nyeri hebat saat bergerak. Klien punya riwayat pembedahan seksio sesarea pada persalinan kedua tahun 2002.

\section{Gambaran kasus 2}

Ny. E.P. 38 tahun, P0 A0. Muslim, ibu rumah tangga (IRT), Laparoskopy Histerektomy Salfingektomy + Oophorectomy sinistra atas indikasi adenomiosis dan kista endometriosis ovarium sinistra. Klien mengeluh nyeri pada perut bagian kiri bawah terutama saat datang bulan (haid), skala nyeri 6, nyeri akan bertambah ketika klien naik motor dan kelelahan dan akan berkurang setelah minum obat. Teraba massa di kuadran kiri bawah sebesar telur ayam. Klien mengatakan cemas untuk menjalani tindakan operasi, dan bertanya apakah ada alernatif lain untuk masalahnya ini selain operasi, karena klien belum punya anak.
Sedangkan operasi ini dilakukan untuk mengangkat rahim dan sumber penyakit yang selama ini saya rasakan. Pernikahan sekarang baru berjalan 5 bulan, sebelumnya pernah menikah selama 3 tahun namun akhirnya cerai karena KDRT. Klien bertanya apakah penyakitnya ini karena ditularkan oleh suaminya karena klien merasakan masalah ini setelah menikah dengan suami kedua. Ada perasaan tampak sedih saat cerita tentang kondisinya saat ini dan kesal terhadap suaminya sekarang. iniPemeriksaan fisik TD: $110 / 70 \mathrm{mmHg}, \mathrm{N}$ : 80x/mnt, S: 36, $4^{\circ} \mathrm{C}$, RR: 20x/mnt, VAS 4-5. Klien punya riwayat pembedahan appendectomy saat SMA.

\section{Pengkajian Kasus}

Riwayat kesehatan

Ny. R.U mempunyai keluhan utama nyeri pada ulu hati yang disertai kembung, mual, dan nyeri pada luka operasi serta banyak keringat. Saat pengkajian klien mengeluh nyeri yang sangat pada ulu hati hingga susah untuk menarik nafas, perut kembung dan klien gelisah. Nyeri seperti ada yang menekan dadanya dari bagian bawah yang terasa tajam dan sakit sekali sehingga klien tidak dapat beraktifitas. VAS: 6, nyeri semakin terasa ketika klien makan dan minum dan berkurang bila klien istirahat. Klien pernah menjalani pembedahan seksio sesaraea tahun 2002, tapi tidak pernah merasakan hal seperti ini. Klien tidak ada alergi makanan dan obatobatan. Ny. E.P mengeluh nyeri pada perut bagian kiri bawah terutama saat datang bulan 
(haid), skala nyeri 4-5, nyeri akan bertambah ketika klien naik motor dan kelelahan dan akan berkurang setelah minum obat. Teraba massa di kuadran kiri bawah sebesar telur ayam. Klien mengatakan cemas untuk menjalani tindakan operasi, dan bertanya apakah ada alernatif lain untuk masalahnya ini selain operasi, karena klien belum punya anak.

\section{Riwayat Obstetri}

Ny. R.U P2A2, P1 lahir spontan, G2 keguguran dan tidak dikuret, didapat klien mengalami mioma tapi tidak dianjurkan untuk diangkat hanya dengan terapi medis, $\mathrm{P} 2$ partus dengan seksio sesarea karena letak lintang klien menikah satu kali, tahun 2003 klien keguguran kehamilan ke 4 dan tidak dikuret. Tidak ada perdarahan melalui kemaluan di luar siklus haid. HPHT: 14 Desember 2014. Sedangkan Ny. E.P P0A0, HPHT 01 Januari 2014, saat haid atau diluar siklus haid beberapa bulan belakang ini klien mengeluh nyeri yang hebat pada daerah perut bagian kiri bawah.

\section{Riwayat Intra operatif}

Ny. R.U dengan tindakan operasi Histerektomi, Salfingektomi, Oophorektomi sinistra (HT SOS) dilaksanakan selama empat jam. Setelah dilakukan adhesiolisis karena adanya perlekatan endometriosis ke organ sekitarnya. Organ yang diangkat pada saat pembedahan uterus, tuba dan ovarium sebelah kiri, dan hidrosalfing sebelah kanan. Begitupula pada Ny. E.P dengan tindakan Laparoskopy Histerektomy Salfingektomy + Oophorectomy sinistra.
Berdasarkan laporan intraoperatif sudah terjadi perlekatan antara uterus bagian korpus belakang dengan rectum. Ovarium kanan tetap dipertahankan karena kondisi dalam batas normal. Bilamana kista tidak segera diangkat lesi dapat menyebar dan merusak jaringan sekitarnya dan kemudian klien akan beresiko mengalami kanker ovarium epitel (Worley, Welch, Berkowitz \& Shu-Wing, 2013)

\section{Kebutuhan Kenyamanan (Comfort)}

\section{Fisik}

Relief: Klien pada kasus 1 (post operasi) mengeluh nyeri pada ulu hati, perut terasa penuh, dan nyeri pada luka operasi, ekspresi wajah tampak tegang, menahan nyeri, klien gelisah, klien tampak memegangi perutnya, klien berkeringat, bising usus positif, perut kembung, belum platus, terdapat nyeri tekan, klien tidak nafsu makan sejak masuk RS, TD:

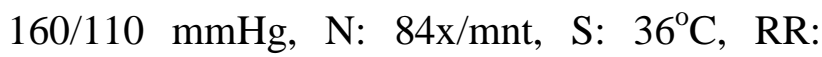
30x/mnt, saturasi O2 98, VAS: 6, CRT: < 3dtk, klien berulang kali menyeka keringatnya dengan handuk, baju klien basah, akral dingin dan klien pucat, fokus klien menyempit, klien tidak bisa tidur tadi malam, mata tampak sayu, terdapat luka vertikal di perut, panjang $15 \mathrm{~cm}$, klien masih terpasang cateter. Klien satu hari post operasi HT SOS (lama operasi 4 jam) karena adanya perlekatan. Leukosit: 10.67 ribu. Ease: Klien menggunakan minyak kayu puth yang dioleskan ke perut kecuali daerah luka, klien menyeka keringatnya dengan handuk kecil, klien berusaha untuk makan dan minum sedikit 
walaupun perut terasa bertambah nyerinya, licin, tempat tidur terdapat handrail, alat tenun klien dapat bersendawa beberapa kali. dan selimut tersedia dan bersih. Ease; Klien di Transendence: Ingin masalah klien dapat rawat di kelas III. Transendence; Klien ingin diselesaikan apapun caranya. Masalah: Nyeri lingkungan ruang rawat nyaman bagi diriya akut, intoleransi aktifitas, resiko tinggi infeksi, Resiko gangguan pemenuhan kebutuhan nutrisi sampai klien pulang. Masalah: Gangguan rasa nyaman.

\section{Psikospiritual}

\section{Sosiokultural}

Relief: Klien cemas dengan kondisinya seperti ini, pembedahan sebelumnya tidak seperti ini masalah yang muncul, klien cemas dan takut suaminya menikah lagi, klien merasa tidak sempurna lagi sebagai seorang istri bagi suaminya karena sudah tidak punya rahim, klien sedih dan menangis saat ceritakan perasaannya, klien menyesali keadaannya saat ini yang sudah berat penyakitnya sehingga rahim harus diangkat, klien mengungkapkan perasaan penyesalan kenapa tidak mengikuti terapi medis sejak dulu sebelum penyakitnya bertambah berat seperti sekarang ini. Klien mengatakan cukup lama berada di ruang operasi. Ease; Klien memegang erat tangan perawat, klien yakin akan kesembuhannya. Transendence: Ingin adanya campur tangan Alloh atas kesembuhan penyakitnya. Masalah

Relief: Support keluarga cukup menurut klien, klien seorang ibu rumah tangga saat ini, sebelumnya klien bekerja sebagai karyawan, klien tidak boleh ditemani oleh keluarga karena peraturan di ruangan, klien hanya boleh dikunjungi pada saat jam besuk dan bila diperlukan oleh ruangan, klien saat pengkajian hanya terbaring di atas tempat tidur, menurut budaya pasien post operasi tidak boleh makan sembarangan, pengetahuan klien tentang penyakitnya kurang. Ease; Suami dan keluarga secara bergantian menemani klien hanya pada saat jam besuk dan bila diperlukan, teman dan saudara datang berkunjung saat jam besuk. Transendence: Klien ingin segera pulang ke rumah karena yakin dirinya akan lebih baik ketika dirumah, sembuh dan menjalankan fungsinya sebagai ibu dan istri.

keperawatan: cemas, berduka

\section{Kehilangan dan Berduka}

\section{Lingkungan}

Relief: Ruangan ber AC, namun tidak berfungsi dengan baik sehingga suhu lingkungan kamar agak panas, kebutuhan klien terpenuhi seperti makan dan minum, pakaian dan dapat terjangkau dengan mudah, kamar mandi tidak

Proses kehilangan yang sedang dialami oleh klien karena adanya stimulus eksternal dan internal menyebabkan klien masih menyangkal dan tidak percaya dengan kehilangan yang dialaminya saat ini. Sifat kehilangan dapat diramalkan karena sudah diberitahu oleh dokter 
sebelumnya. Klien kehilangan anggota badan yaitu rahim, kedua saluran telur dan ovarium sebelah kiri. Kategori kehilangan yang dialami oleh klien termasuk kehilangan aspek diri, dimana ada bagian dari tubuh klien yang dianggap sangat berarti sebagai seorang perempuan dan istri yaitu kehilangan rahim.

Respon dan perilaku klien pada fase-fase kehilangan: 1) fase denial: Klien mengatakan apakah benar rahimnya telah diangkat, klien gelisah dan cemas, 2) fase anger: klien marah pada dirinya sendiri karena semua ini terjadi akibat dirinya tidak mengikuti saran dari dokter untuk pengobatan dari sejak awal, 3) fase bargaining: klien mengungkapkan pernyataan "kalau boleh memilih klien ingin kembali ke saat dimana dia harus menjalani pengobatan tanpa harus operasi pengangkatan rahim", 4) fase depresi: klien sedih dan menangis saat bercerita, merasa tidak ada harganya lagi sebagai seorang perempuan, klien takut suaminya menikah lagi karena klien sudah tidak bisa melayani lagi, dan 5) fase acceptance: klien belum dapat menerima kenyataan saat ini baik secara verbal dan nonverbal. Stress psikologis klien mempengaruhi kondisi fisik klien seperti gelisah, berkeringat banyak, tekanan darah meningkat, nyeri semakin hebat walau sudah dilakukan intervensi. Masalah keperawatan: berduka, gangguan body image.

\section{Diagnosa Keperawatan}

1. Nyeri akut b.d iritasi saluran pencernaan; kembung dan adanya luka insisi pembedahan

2. Berduka b.d kehilangan anggota tubuh, histerektomi

3. Resiko tinggi infeksi b.d adanya trauma insisi pembedahan

4. Resti manajemen terapeutik inefektif b.d kurangnya pengetahuan

5. Intoleransi aktifitas b.d kelemahan

6. Resiko gangguan pemenuhan kebutuhan nutrisi b.d tidak nafsu makan

7. Cemas b.d kurangnya informasi,

8. Gangguan body image b.d diangkatnya rahim

\section{Implementasi}

Rencana tindakan keperawatan yang diberikan sesuai keadaan here and now yang terjadi pada klien saat asuhan diberikan, dengan tujuan untuk mengatasi ketidaknyamanan pada klien baik secara fisik yaitu adanya nyeri pada ulu hati dan luka operasi; psikospiritual yaitu kehilangan rahim dan cemas dengan respon suaminya nanti karena klien merasa tidak sempurna lagi sebagai seorang perempuan dan istri; lingkungan yaitu suhu kamar agak panas sehingga klien kegerahan; sosiokultural yaitu klien tidak boleh ditemani atau ditunggui oleh keluarga saat dirawat. Prinsip tindakan adalah memfasilitasi klien untuk mendapatkan kenyamanan pada seluruh aspek dan membuat klien dapat menerima kehilangan yang terjadi dan menunjukkan perilaku yang adaptif pada setiap fase kehilangan. 


\section{Evaluasi}

Hasil evaluasi menunjukkan pencapaian kenyamanan (enhanced comfort) sehingga klien dapat menunjukkan perilaku mencari kesehatan (Health Seeking Behavior) yang lebih positif.

\section{Pembahasan}

Berdasarkan hasil kelolaan dua kasus klien dengan kista endometriosis. Peneliti dapat menerapkan konsep teori comfort dan loss \& grief secara bersamaan dan saling memperkuat satu dengan yang lainnya. Kasus pertama pada klien Ny. R.U, usia 44 tahun belum menopause, peneliti hanya dapat memberikan asuhan keperawatan pada waktu postoperatif sedangkan pada kasus kedua pada klien Ny. E.P, usia 38 tahun, siklus menstruasi normal setiap bulan dan belum memiliki keturunan peneliti memberikan asuhan keperawatan sejak perawatan preoperative sampai dengan post operatif.

Klien Ny. R.U dilakukan tindakan operasi laparotomi histerektomi radikal, salfingektomi bilateral dan oophorektomi sinistra, sedangkan pada klien Ny. E.P tindakan pembedahan yang dijalani yaitu laparoskopi histerektomi, salfingektomi bilateral dan oophorektom sinistra. Usia klien pada kedua kasus berada pada rentang perempuan usia subur, seperti beberapa literatur mengatakan bahwa kejadian kista endometriosis terjadi pada perempuan usia subur.

Dysmenarche atau nyeri pada saat haid atau diluar siklus haid pada perempuan usia subur harus diwaspadai dengan cermat, karena merupakan gejala yang sangat signifikan dan selalu dilaporkan oleh klien yang mengalami endometriosis (Harzif, 2014; Ricci \& Kyle, 2009; Ozkan \& Arici, 2009). Walaupun respon nyeri masing-masing individu sangat bervariasi karena tergantung ambang nyeri yang dimiliki. Semua kasus kelolaan yang dilaporkan dan kasus sama yang ada di rumah sakit, peneliti menemukan nyeri menjadi masalah utama bagi klien dan terus menerus dialami oleh klien dan terberat dirasakan oleh klien saat siklus menstruasi datang setiap bulan sebelum tindakan operasi dilakukan. Bahkan hampir semua klien mengatakan saat nyeri datang klien mengalami gangguan saat melakukan aktifitas bahkan sampai mual muntah.

Nyeri bersifat subyektif dan sering dipersepsikan klien sebagai suatu tanda penurunan kondisi kesehatan klien sehingga sering menjadi alasan klien menjadi tidak berdaya dan terlalu bergantung pada orang lain untuk membantu memenuhi kebutuhannya baik pada tahap pre operasi maupun tahap post operasi. Sehingga memicu ketakutan dan kecemasan klien yang akhirnya dapat memacu epinefrin diproduksi berlebihan dan akhirnya respon nyeri semakin bertambah berat. Oleh karena itu, membantu klien mengatasi nyeri dengan teori comfort diharapkan dapat membuat klien dapat beradaptasi dengan menunjukkan perilaku adaptif dan memberi respon dan perilaku yang menunjukkan peningkatan kenyamanan. 
Kedua kasus kelolaan semua klien sudah

Masalah medis kista sering terjadi pada perempuan usia subur dan sering dikaitkan dengan perihal kesuburan seorang wanita (Matalliotakis, et al. 2010). Masalah infertil primer dan sekunder peneliti temukan pada kedua klien kelolaan. Nyeri dan infertil yang terjadi pada klien dengan kista endometrium dapat menghancurkan dan berpengaruh terhadap kondisi fisik, mental dan kehidupan sosial seorang perempuan serta kualitas hidupnya secara keseluruhan (Ozkan \& Arici , 2009).

Kasus kista endometriosis juga dapat dialami oleh perempuan usia subur yang belum menikah karena penyakit kista endometriosis terjadi dengan penyebab yang belum jelas namun dari beberapa literatur diperoleh informasi penyebabnya kemungkinan terjadi menstuasi retrograde melalui tuba akhirnya sel endometrium keluar dan tumbuh di luar kavum uteri dan berasal dari keadaan endometritis kronik (Bernardi \& Pavone, 2013; Takebayashi, 2014). Namun berdasarkan hasil pengkajian peneliti tidak menemukan riwayat penyakit endometritis yang ditegakkan pada klien, hal ini kemungkinan karena tidak adanya gejala yang mengganggu klien seperti nyeri pada panggul, perdarahan, keputihan dan dyspareunia (Takebayashi, 2014) atau karena klien selama ini menganggap nyeri pada saat haid yang tidak sangat menggangu adalah biasa terjadi pada perempuan. menikah, namun aplikasi asuhan pada kasus 1 peneliti belum maksimal melibatkan keluarga terutama suami klien karena suaminya tetap harus bekerja dan datang ke rumah sakit pada malam hari. Kasus kedua klien baru menikah lima bulan yang lalu, pernikahan kedua, menurut klien pernikahan sebelumnya hanya bertahan 3 minggu karena suami main tangan, klien cerai. Kedua klien sebelumnya adalah perempuan pekerja, namun karena penyakit dan menjalani pengobatannya semua klien keluar dari tempat kerjanya. Klien merasakan nyeri yang hebat pada saat haid maupun di luar siklus haid terutama pada klien Ny. E.P. sehingga mengganggu klien saat bekerja dan akhirnya klien keluar dari pekerjaannya.

Masalah keperawatan yang muncul dari kasus 1 (Ny. R.U) nyeri akut berhubungan dengan iritasi saluran pencernaan; kembung dan adanya insisi pembedahan, berduka berhubungan dengan kehilangan anggota tubuh; histerektomi, resiko tinggi infeksi b.d adanya trauma insisi pembedahan, resti manajemen terapeutik inefektif b.d kurangnya pengetahuan, intoleransi aktifitas b.d kelemahan, resiko gangguan pemenuhan kebutuhan nutrisi b.d tidak nafsu makan, cemas b.d kurangnya informasi, gangguan body image b.d diangkatnya rahim. Sedangkan pada kasus 2 (Ny. E.P) masalah preoperatif: cemas b.d tindakan pembedahan; histerektomi, masalah postoperatif: nyeri akut b.d adanya trauma 
jaringan akibat insisi pembedahan, berduka b.d kehilangan anggota tubuh; histerektomi, resiko tinggi infeksi b.d adanya luka insisi pembedahan, dan intoleransi aktifitas b.d kelemahan.

Diagnosa keperawatan nyeri ditegakkan pada semua kasus kelolaan baik pada lima kasus sebelumnya dan dua kasus yang menerapkan teori keperawatan comfort dan loss \& grief. Karena adanya lesi kista saat sebelum pembedahan akan menyebabkan nyeri ringan hingga berat pada klien terutama pada saat klien haid. Setelah pembedahan, dengan adanya insisi dan kemungkinan munculnya komplikasi paska pembedahan akan menimbulkan ketidak nyamanan tersendiri bagi klien.

Masalah berduka dan cemas menjadi masalah prioritas kedua karena pada semua klien yang mengalami kista endometriosis sudah berada pada tahap endometriosis berat, dimana tidak cukup dengan tindakan terapi pengobatan saja tapi harus ditatalaksana dengan pembedahan untuk pengangkatan kista atau organ saluran reproduksi dimana kista tumbuh dan berkembang. Kehilangan organ reproduksi sebagian atau keseluruhan sehingga tidak dapat berfungsi lagi setelah pembedahan dapat menimbulkan masalah berduka sebagai respon emosional terhadap kehilangan (Keliat, 2009).
Selain itu masalah resiko tinggi terjadi infeksi penulis tegakkan pada kedua kasus karena dengan adanya luka, terpasangnya alat-alt kesehatan dan ketidaktahuan klien tentang perawatan luka. Tujuan diberikan perawatan pada masalah ini adalah salah satu komplikasi pembedahan yaitu terjadinya infeksi pada klien setelah tindakan pembedahan tidak dialami oleh klien, karena masalah ini hanya akan menambah masalah baru bagi klien yang akhirnya akan menimbulkan ketidaknyamanan yang lain.

Intervensi dan implementasi keperawatan yang dilakukan berdasarkan diagnosa keperawatan yang muncul pada klien. Menggunakan teori comfort, peneliti memberikan tindakan yang memfasilitasi klien untuk mengatasi masalah yang dialami selama proses keperawatan perioperatif dengan melihat bahwa individu adalah mahluk yang unik dan memiliki respon yang berbeda (Perry \& Poter, 2005). Intervensi yang dirumuskan untuk mengatasi klien antara lain manajemen nyeri efektif, pemenuhan kebutuhan sehari-hari untuk meningkatkan rasa nyaman klien, ciptakan lingkungan yang kondusif bagi klien, menggunakan komunikasi terapeutik untuk mengeksplorasi perasaan kehilangan dan dapat menunjukkan koping yang efektif pada setiap tahap berduka, motivasi klien untuk kehidupannya di masa depan dan melibatkan support system yang dimiliki. Mengatasi nyeri yang menjadi masalah prioritas pada seluruh kasus klien dengan kista 
endometriosis (Ozawa, Murakami \& Terada, 2006; Ozkan dan Arici, 2009) dengan teori Comfor, tindakan yang dilakukan menggunakan konsep standar comfort, coaching dan comfort food dan intervensi untuk menghadapi proses berdukanya karena kehilangan rahim dengan maenggunakan konsep intervensi sesuai LossGrief.

Seorang individu yang kehilangan mengalami fase-fase berduka yang dikemukan oleh KublerRoss pada tahun 1996, yaitu: 1) fase denial (tidak percaya atau menolak kenyataan), 2) anger (perasaan yang meningkat dan diproyeksikan pada orang lain atau diri sendiri), 3) bargaining (tawar menawar dengan kondisi yang dialami saat ini, individu senang berandaiandai, 4) depression (bersedih yang mendalam, cenderung menarik diri dan terkadang mengungkapkan keputusasaan serta perasaan tidak berharga, dan 5) acceptance (menerima kenyataan kehilangan dengan perilaku lebih adaptif) (Perry \& Poter, 2005). Disetiap fase berduka itu perawat mendampingi klien agar dapat melewati fase berduka dan menerima kehilangan yang dialami

\section{KESIMPULAN}

Permasalahan klien dengan kista endometritis yang ditatalaksana dengan pembedahan identik dengan rasa ketidaknyamanan yang terjadi baik secara fisik, psikospiritaul, lingkungan dan sosiokultural pada tahap pre operatif, intra operatif dan post operatif. Kemudian tindakan pembedahan sendiri memiliki komplikasi yang dapat terjadi pada klien setelah pembedahan. Akibat efek samping pembedahan seperti perdarahan, gangguan pencernaan, infeksi dan lainya, serta efek jangka panjang yaitu kehilangan organ tubuh yang penting bagi seorang perempuan karena kondisi kista endometriosis yang berat.

Pemberian asuhan keperawatan pada seluruh kasus pasien yang ditemukan harus secara holistik, karena manusia adalah mahluk holistik. Penerapan teori keperawatan pada asuhan keperawatan klien dapat diterapkan bersamaan dengan teori lain agar asuhan yang diberikan lebih intensif dan komprehensif. Pelayanan asuhan keperawatan khususnya pada klien kista endometriosis ditatanan klinik sebaiknya tidak hanya memperhatikan segi atau aspek fisik dan hanya bersifat rutinitas saja, karena klien adalah mahluk yang unik dan berbeda satu dengan yang lain walaupun diagnosa medis mereka sama.

\section{SARAN}

Penggunaan teori comfort dan loss \& grief sudah dapat maksimal mengatasi masalah klien saat asuhan diberikan, namun kualitas hidup klien sesudah perawatan, ketika klien kembali ke tengah keluarga dengan segala keterbatasan yang diyakini dan dimiliki oleh klien yaitu tidak memiliki rahim lagi peneliti menyarankan teori keperawatan Health-related quality of live dapat diaplikasikan pada kondisi klien yang 
kemungkinan mengalami komplikasi penyakit atau komplikasi paska operasi, serta teori self- efficacy pada pasangan yang belum memiliki keturunan setelah penatalaksanaan kista endometriosis maksimal dilakukan untuk perencanaan memiliki anak.

\section{KEPUSTAKAAN}

Bernardi, L.A., \& Pavone, M.E. (2013). Endometriosis: an update on management. Women Health, 2013. 9(3). 233-250.

Daniels, R., Grendell, R.N., \& Wilkins, F.R. (2010). Nursing fundamentals, caring \& clinical decision making. second edition. USA: Delmar Cencage Learning

Harzif, A.K. (2014). Apakah kista ovarium ganggu kesuburan. Halo Cipto, Media informasi dan edukasi RSCM. Edisi November, 1784 2014. Hal 7, ISSN 1411-

Iafrate, F., Ciolina, M., Lanitti, M., Baldassari, P., Pichi, A., Rengo, M., De Cecco, C.N., \& Laghi, A. (2012). Gallbladder and muscular endometriosis: case report. Abdomen Imaging, 2013 38:120-124. Doi: 10.1007/s00261-012-9879-1

Keliat, Budi Anna. (2009). Proses Keperawatan Jiwa. Jakarta: ECG.

Kim, S.H., Chae, H.D., Kim, C. \& Kang, B.M. (2013). Update on treatment of endometriosis. Clin Exp Reprod Med (CERM) 2013;40(2). 55-59

Kolcaba, K., Tilton, C. \& Drouin, C. (2006). Comfort theory; Unifying framework to enhance the practice environment. JONA. Vol. 36. 11. 538-544

Matalliotakis, I.M., et al. (2010)
Endometriosis related to family history of malignancies in the Yale series. Surgical Oncology (2010). 19, 33-37.

Murray, S.M. \& McKinney, E.S. (2007). Foundation of maternalNewborn nursing. $4^{\text {th }}$ edition. Singapore: Elsevier

Ozawa, Y., Murakami, T., Terada, Y., et al. (2006). Management of the pain

associated with endometriosis: an update of the painful problems. Tokoku. J. Exp. Med. 210: 175-188.

Ozkan, S. \& Arici, A. (2009). Advances in treatment options of endometriosis. Gynecology and Obstetric Investigation. 2009;67: 81-91.
10.1159/000163071

Doi:

Doi: 10.1016 


\section{Mosby/Elsivier}

Worley, M.J., Welch, W.R., Berkowitz, R.S., \& Ng, S.W. (2013). Endometriosis- associated ovarian cancer: a review of pathogenesis. International Journal Melecular Sciences. 2013, 14,53675379; doi: 10.3390/ijms 14035367

Yamashita, Y. \& Toyokuni, S. (2012).

Endometriosis-associated ovarian cancer, The role of oxidative stress. ISBN: 978-95351-0524-4. 